\title{
平面噴流の発達に及ぼす周期かく乱の効果*
}

\author{
森島隆二*1, 早川道雄*2, 飯田誠一*3
}

\section{Effect of Periodic Disturbances on the Development of a Planar Jet}

\author{
Ryuji MORISHIMA, Michio HAYAKAWA*4 and Sei-ichi IIDA
}

${ }^{* 4}$ Hokkaido University, Graduate School of Engineering, N13 W8, Sapporo, Hokkaido, 060-8628 Japan

\begin{abstract}
Effects of periodic disturbances on the development of a two-dimensional jet issuing from a contraction nozzle were studied experimentally. The disturbances were fed into the jet at the nozzle lips so as to excite the opposing shear layers with either symmetric or antisymmetric mode of velocity fluctuation. The forcing Strouhal number $S t_{e}$, based on forcing frequency and nozzle width, was varied in the range of $0.08-1.2$. The symmetric forcing at $S t_{e} \fallingdotseq 0.4$ and 0.8 increased the jet entrainment rate through frequency-halving processes. The maximal change of the jet width was achieved by the antisymmetric forcing at $S t_{e} \fallingdotseq 0.1$, which promoted the jet flapping motion in the region beyond the potential wedge.
\end{abstract}

Key Words: Planar Jet, Active Control, Periodic Forcing, Symmetric Disturbance, Antisymmetric Disturbance

\section{1.はじめに}

二次元自然噴流中の基本的な不安定モードとして, 「対称形」と「反対称形(または, 逆対称形)」の二つ の変動があることはよく知られている(1)(2). 通常, 櫴 流出口高さの 6 9 倍までは対称形の変動のほうが優 勢で, 噴流中心線に関して対称に配列した渦構造が形 成されやすい，それより下流においては反対称形の変 動の増幅度のほうが高くなり, 噴流の蛇行運動(フラ ッピング運動)をもたらす。そして,この蛇行運動に は交互配列の渦構造が関与しているようであ る(3) (6). したがって，人工かく乱を与えて平面噴流の 発達を人為的に操作する場合, 対称形と反対称形のど ちらの変動モードを用いるかによって, 噴流の発達に 及湾す効果もおのずから異なると考えられる。

層流ポアズイユ流れを初期条件にもつ平面噴流につ いては, 蒔田らの一連の研究(7)(8)によって, 対称と反

* 原稿受付 1999 年 8 月 25 日.

*1 正員, (株) タボタ (画 103-8310 東京都中央区日本橋室町 3 丁 目).

*2 正員, 北海道大学大学院工学研究科(\$060-8628 札幌市北区 北 13 条西 8 丁日).

*3 正員, 北海道立工業試験場 (画060-0819 札棍市北区北 19 条 西 11 丁目). 北海道大学名誉教授.

E-mail : haya@eng.hokudai.ac.jp
対称かく乱で励起したときの流れ場が詳細に調べられ ている。これに対し，縮流ノズルから流出する噴流の 励起実験は多数行われているにもかかわらず(9) (12), 対称と反対称かく乱の両方を扱った実験結果は棌とん ど報告されていない(2)。

本実験研究は, 二次元縮流ノズルの両側の出口端に 設けたスリットから，互いの位相差を設定できる周期 汃く乱を導入する方法によって, 矩形速度分布を初期 条件とする平面噴流の発達に及注す対称と反対称形の かく乱の効果を調べたものである.

\section{2. 実 験 装 置}

$2 \cdot 1$ 二次元風洞と測定装置実験は一辺 800 $\mathrm{mm}$ の正方形断面の整流胴をつ低速吹出し形風洞 で行った。整流胴内には八ニカム一段と金網 3 枚が挿 入されており,これに縮流比 $19: 1$, 長さ $1.2 \mathrm{~m} の 2$ 次元縮流部が取付けられている。縮流部の形状は, 飯 田(13)の提案した設計法に基づいて決定した。その下 流端にさらに $50 \mathrm{~mm}$ の平行延長部を設け，そこに人 工かく乱発生装置を設置した。噴流出口断面の高さと 幅は，それぞれ $H=42 \mathrm{~mm}, W=800 \mathrm{~mm}$ であり,ア スペクト比 $(W / H)$ は 19 である.

流れ場の計測にはおもに定温度形熱線風速計を用い 
た. 熱線は線径 $5 \mu \mathrm{m}$ のタングステン線で, プローブ は受感部長さが約 $1 \mathrm{~mm}$ の I 形である. 風速計の出 力電圧信号を $\mathrm{A}-\mathrm{D}$ 変換器を介して, パーソナルコン ピュータに集録し，オフライン処理した。 A-D変換 の時間間隔とサンプル数は $0.2 \mathrm{~ms}$ で 32000 点, また は $0.5 \mathrm{~ms}$ で 20000 点である. 実験時における噴流出 口流速は，あらかじめ標準ピトー管を用いて検定した 出口動圧とノズル前後の壁面静圧差の関係から算出し た。またこれを熱線の校正にも利用した。

\section{$2 \cdot 2$ 人工かく乱発生装置 人工汃く乱の発生に} はスピーカの膜面振動を利用した。かく乱発生装置は 2 チャネル独立出力をもつ信号発生器 (エヌエフ回路 設計ブロック社製), ステレオ用増幅器, 2 個のスピー 力，および導波箱から成っている。スピーカには定格 出力 100 Watt のウー八 (Fostex 社製) を用いた. そ の口径は $250 \mathrm{~mm}$ ，最低共振周波数は $25 \mathrm{~Hz}$ である。 かく乱はノズル左右壁の先端中央部に設けたスリット から流れ内に注入される. スリットのすきまは約 1 $\mathrm{mm}$, 幅は $300 \mathrm{~mm}(=0.38 \mathrm{~W})$ である. 図 1 に噴流出 口付近の水平断面略図を示す。

本かく乱発生装置により，原理的には風洞の特性や 気流流速とは無関係に, 任意の振湢と位相差をもつか く乱を左右せん断層中に与えることができる。本実験 では励起信号に正弦波を用いた，左右の位相差が零の とき対称形かく乱による励起 (以下, 対称励起)， $\pi$ の とき反対称かく乱による励起 (反対称励起)である.

以下で使用する座標系は噴流出口断面の中央を原点 として，下流方向へ $x$, これと鉛直方向に $y$, これら と直角方向に $z$ とする(図 1)。なお，本実験に扔ける 流れ方向の測定範囲は $x / H=15$ までである。

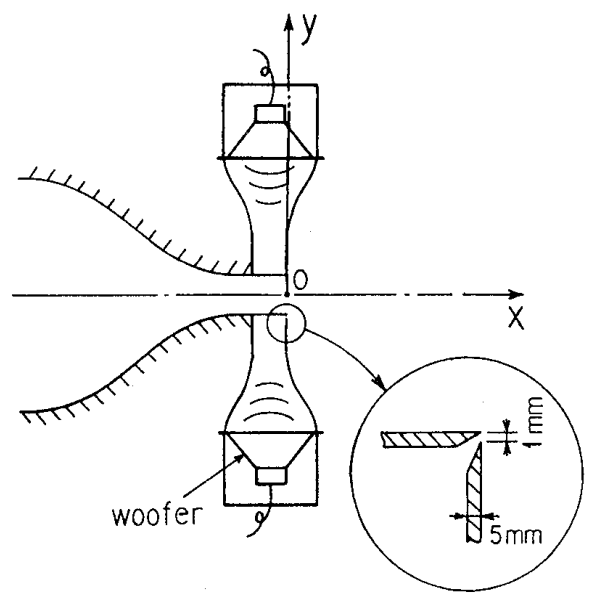

Fig. 1 Schematics showing the plan view near the jet exit section; not in scale

\section{3. 測定条件と励起強さ}

$3 \cdot 1$ 測定条件 実験はおもに出口中心流速 $U_{j}=$ $10.2 \pm 0.2 \mathrm{~m} / \mathrm{s}$, レイノルズ数 $R e\left(=U_{j} H / \nu\right) \simeq 2.9 \times 10^{4}$ ( は空気の動粘度)の下で行った。このとき, 出口中 心における流れ方向速度成分の乱れ度は $0.52 \%$ であ った. 出口断面の $y=0$ における平均流速は約 700 $\mathrm{mm}$ の範囲 $(z / W< \pm 0.44)$ で一様であった。また，測 定した最下流の位置 $x / H=15$ において, 噴流中心流 速がz方向に一様とみなせる範囲は技よそ $400 \mathrm{~mm}$ であった，ただし，これらはピトー管による測定結果 であり, 各z断面における速度分布や乱れ成分の二次 元性の吟味は行っていない.

図 2 に噴流中心線上の平均流速 $U_{0}$ と速度変動強さ 裉を従来のいくつかの結果(14)(15)(6) とともに示す. $U_{0}$ とル゚はいずれもレイノルズ数だけでなく, 測定環境 (装置や初期条件)の違いによっても少なからず異なっ ている.

$3 \cdot 2$ 流入かく乱の強さ(励起強さ) 風洞内部の 気流を振動させる方法 ${ }^{(10)}$ とは異なり, 本手法では流 れに与えたかく乱の強さを客観的に決めることが難し い.ここではかく乱導入スリットの下流， $x=2 \mathrm{~mm}$ の断面において測定した速度変動の策効值の最大值を もって，注入かく乱の強さとみなし，これを $U_{j}$ で除 した值を励起強さ $a$ と定義した. 最大值となる yの

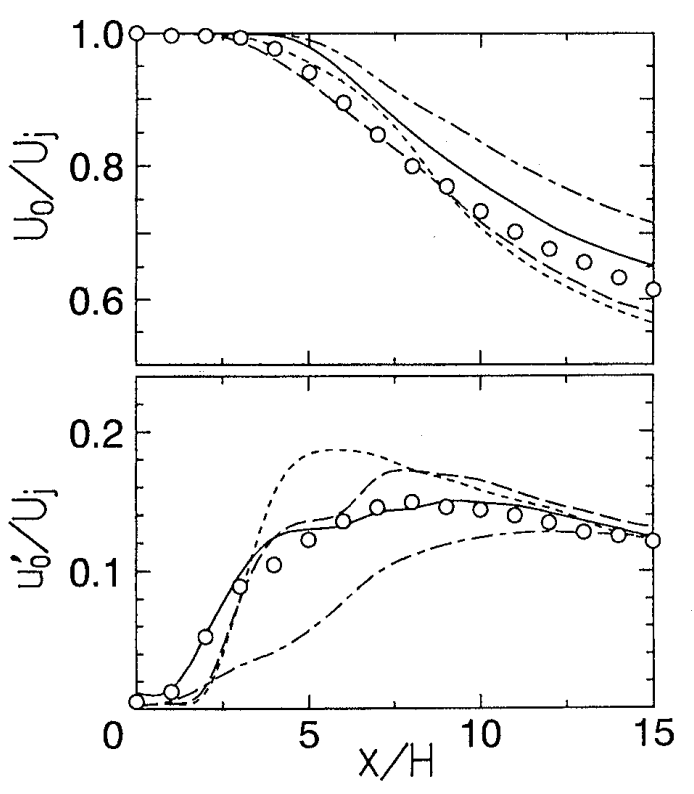

Fig. $2 U$ and $u$ ' on the jet centerline $\cdots$.... Chambers et al. ${ }^{(15)}(R e=7600)$ ----Thomas \& $\mathrm{Chu}^{(6)}(\mathrm{Re}=8300)$ -Hussain \& Clark $^{(14)}(\mathrm{Re}=32600)$ -.-Hussain \& $\mathrm{Clark}^{(14)}(\operatorname{Re}=81400)$ $\bigcirc$ Present result $(R e=29000)$ 
位置は 土20.5 mmであった。

周期かく乱を発生するのに用いたスピーカの周波数 特性は既知 ( $2 \mathrm{kHz}$ までほほ平たん)であるが，かく乱 発生装置全体の周波数特性は末知である。このため, 励起強さとスピーカ入力電圧との関係を周波数ごとに あらかじめ検定実験で求めた。この関係は周波数に強 く依存し, 実験した周波数範囲 $f_{e}=20 \sim 280 \mathrm{~Hz}$ のす べてに共通に与えることのできた励起強さは $6 \%$ 程度 までであった。

かく乱の波形は $f_{e}>80 \mathrm{~Hz}$ の範囲ではほぼ正弦波で あったが，これ以下で高調波成分の重畳するのが認め られた。この波形のひずみが以下の結果に与える影響 は少ないと推測しているが, 詳しい評価は行っていな い. 左右のスリットからのかく乱の位相差 (零と $\pi$ ) は良好であったが，左右の振幅はわずかに異なってい たため，雨振幅が一致するように片側のスピー力入力 電圧を調整した。

\section{4. 実 験 結 果}

$4 \cdot 1$ 非励起時の流れ 図 2 の結果からもわかる ように，励起実験の結果を評価するうえでままず本装 置における非励起時の噴流 (自由噴流)の特性を明確に しておくことは重要である。

図 3 に $x \simeq 1 \mathrm{~mm}$ で測定した初期境界層の速度 $U$ と変動強さ ( $u^{\prime}, \mathrm{rms}$ 值)の分布を示卞. 左右の層流境 界層の特性はほほ一致している。風洞縮流部の後半の 断面積変化が緩やかで，さらに $50 \mathrm{~mm}$ の平行延長部 があるため，境界曆が比較的に厚くなって招り， $99.5 \%$ 厚さ, 排除厚さ，および運動量厚さはそれぞれ $\delta=3.35 \mathrm{~mm}, \delta^{*}=0.98 \mathrm{~mm}, \theta=0.40 \mathrm{~mm}, \delta^{*} / \theta=2.45$ である。

図 4 は出口中心，および図 3 の u’が最大になるy

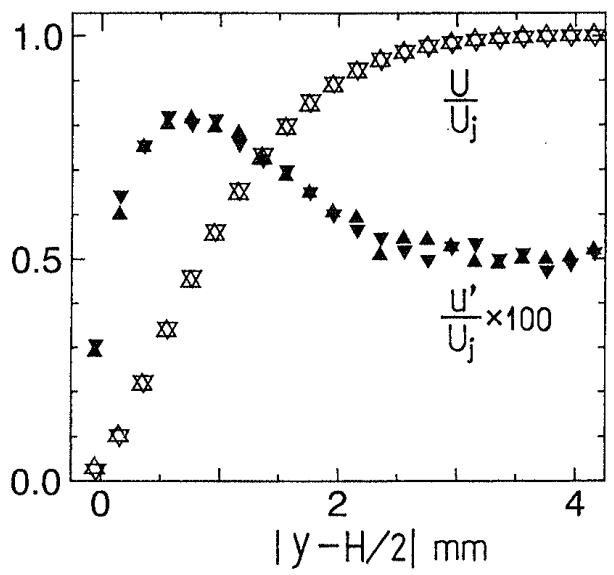

Fig. 3 Boundary layer characteristics on both sides at the jet exit section
位置に抒ける速度変動の周波数スペクトルである，主 流中には $f=11,39,65 \mathrm{~Hz}$ にピーク, $f \simeq 265 \mathrm{~Hz}$ に明 りょうな盛上がりが存在し, 後者は境界層内でより顕 著になっている。これらは熱線プローブや指示棒の長 さを変えても同様に観測された。したがって，いずれ も使用した風洞に笴生するものと考えられる，境界層 内に見られる $f \simeq 395 \mathrm{~Hz}$ の盛上がりの発生原因は明 らかではないが, 後述の出口直後のせん断層に現れる 変動のフィードバック作用に起因するように思われ る。ちなみに, この周波数はレイノルズ数 $U_{j} \delta^{*} / \nu=$ 760 に対して $2 \pi f \nu / U_{j}^{2} \fallingdotseq 350 \times 10^{-6}$ となり，境界層の不 安定波としては高すぎるようである(16).

図 5 はポテンシャルくさび領域における速度変動の スペクトル振幅 $\widehat{u}(f)$ である。横軸は無次元周波数で

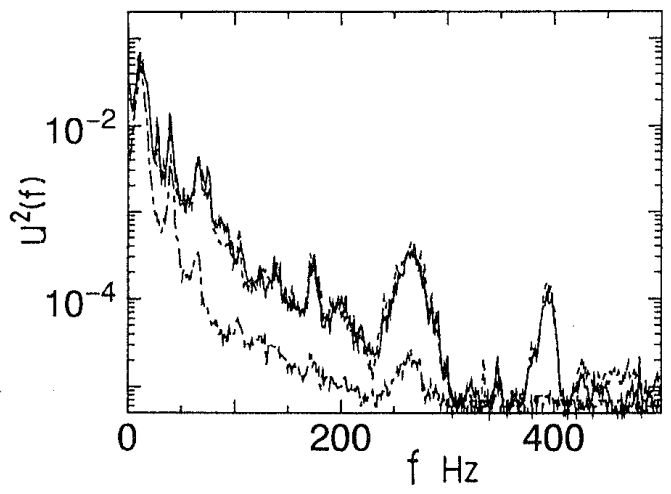

Fig. 4 Power spectra of $u$ fluctuation at the jet exit section

- - - : at $y=0$

$\ldots,---$ : in the boundary layers

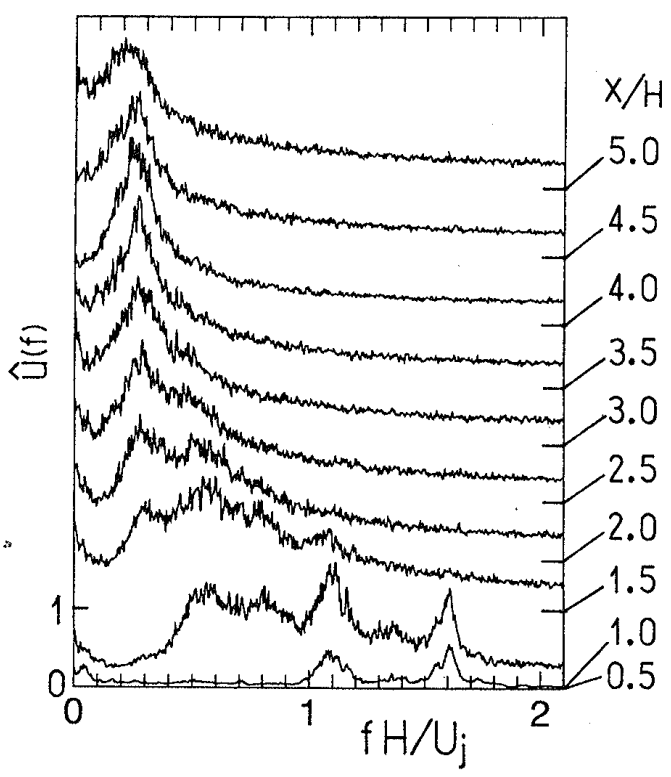

Fig. 5 Frequency spectra at the edge of a mixing layer. Ordinate shows spectral amplitude in arbitrary linear scale. Note shift in origin 
表した。測定位置はせん断層の内縁, $U=0.95 U_{j}$ と なる $y$ 位置(ただし， $x / H>3.5$ では $y=0)$ である。出 口直後では $f H / U_{j} \simeq 1.1,1.6$ の成分が卓越している. これらの周波数は図 4 中の $265,395 \mathrm{~Hz}$ に対応してお り，初期境界層運動量厚さに基づくストローハル数は $f \theta_{e} / U_{j} \simeq 0.011,0.016$ である. 前者は增幅かく乱の振 幅が最大になる変動モードに，後者は增幅率が最大の モードに近い(17)，前者は風洞気流中にすでに存在して いるために，特に顕著に現れたものと思われる。

一方, $x / H=3 \sim 4$ に打汀る $u$ 変動の卓越ストロー ハル数，すなうち本噴流の卓越モード (Jet preferred mode) は $0.25 \sim 0.27$ であり, 従来の結果 ${ }^{(18)}$ とほ湾一 致している.

$4 \cdot 2$ 励起の周波数と振幅の効果 励起周波数 $f_{e}$ の違いが噴流の発達に及ぼす効果のおおよそを知るた め，まず励起強さを $4 \%$ に固定し，噴流中心線上の平 均流速 $U_{0}$ の $f_{e}$ に対する変化を調べた。 $x / H=12,15$ における結果を図 6 に示す。縦軸は非励起時における 值との比で, 横軸は無次元励起周波数 $S t_{e}=f_{e} H / U_{j}$ で 表示してある。

対称励起では広い周波数範囲にわたって $U_{0}$ が增す 傾向にあり, 特に $S t_{e}=0.4,0.8$ 付近で最も大きな変化 を示している。一方, 反対称励起の場合には $S t_{e}=0.1$ 付近で $U_{0}$ が減少している。

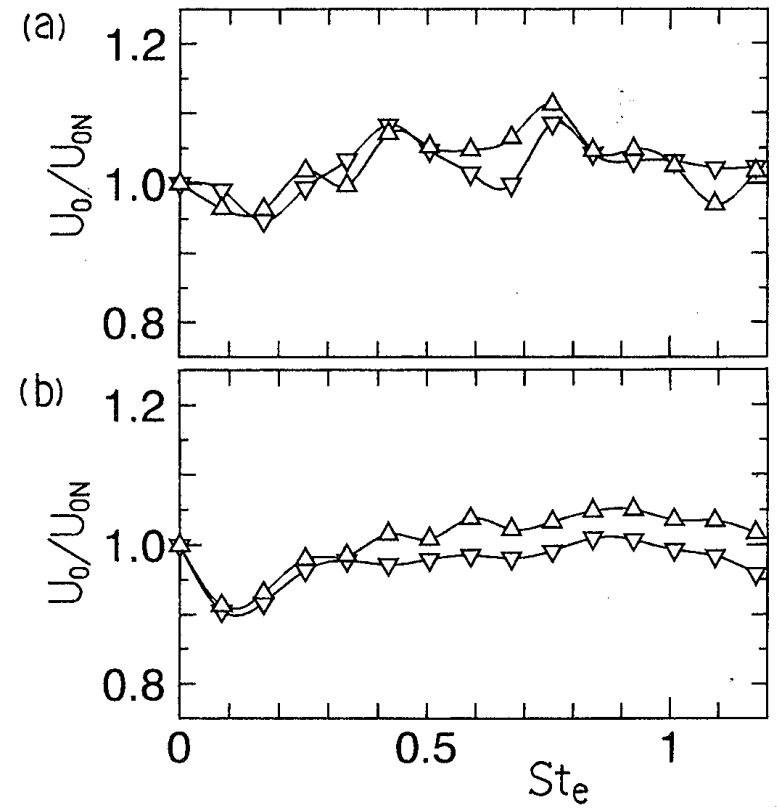

Fig. 6 Variation of $U_{0}$ with forcing frequency. ( $U_{O N}$ denotes $U_{0}$ for the unforced case)

(a) Symmetric forcing $(a=4 \%)$.

(b) Antisymmetric forcing $(a=4 \%)$.

$\nabla: x / H=12, \triangle: x / H=15$
これらの特徵的な励起周波数について励起強さによ る $U_{0}$ の変化を調べた結果(図は略す), 対称励起の場 合 $S t_{e} \fallingdotseq 0.4$ のとき $a \fallingdotseq 4 \%, S t t_{e} \fallingdotseq 0.8$ のと $a \fallingdotseq 6 \%$ よりも強いかく乱を与えても，励起の効果は変的らな いことがわかった。また，反対称励起 $\left(S t_{e} \fallingdotseq 0.1\right)$ では $a=8 \%$ (この周波数で与えることのできた最大の強 さ)で中心速度が最も低下した。

$4 \cdot 3$ 励起による速度場の変化 $4 \cdot 2$ 項の結果に 基づき，次の三と扔りの励起条件の下で速度場の変化 を調べた。

対称励起：

$S t_{e} \fallingdotseq 0.4(a=4 \%)$,

および

$S t_{e} \fallingdotseq 0.8(a=6 \%)$,

反対称励起：

St $t_{e} \fallingdotseq 0.1(a=8 \%)$,

これらの励起条件に扔ける噴流半値半幅 $b$ と断面 流量 $Q$ の $x$ 方向変化を非励起時の值とともに図 7 (a)，（b）に示す。ここで, 流量は出口流量 $Q_{e}$ を差 引いた増加分 (連行量)を無次元化して表した。対称励

(a)

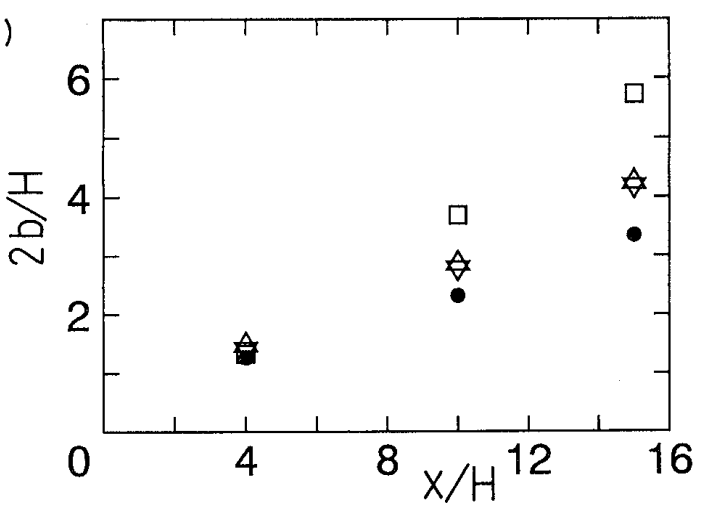

(b)

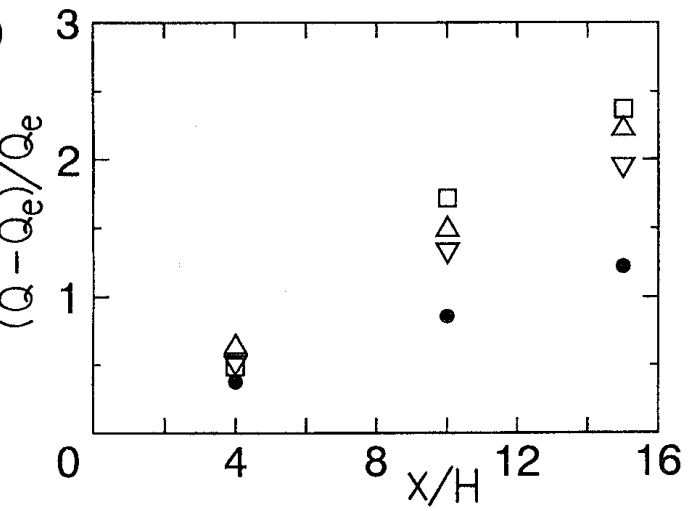

Fig. 7 Influence of forcing on the jet growth. (a) Half width. (b) Entrainment rate.

$\nabla: S t_{e}=0.41$ (symmetric), $\triangle: S t_{e}=0.76$ (symmetric), $\square: S t_{e}=0.11$ (antisymmetric), $\bullet$ : unforced case 
(a)

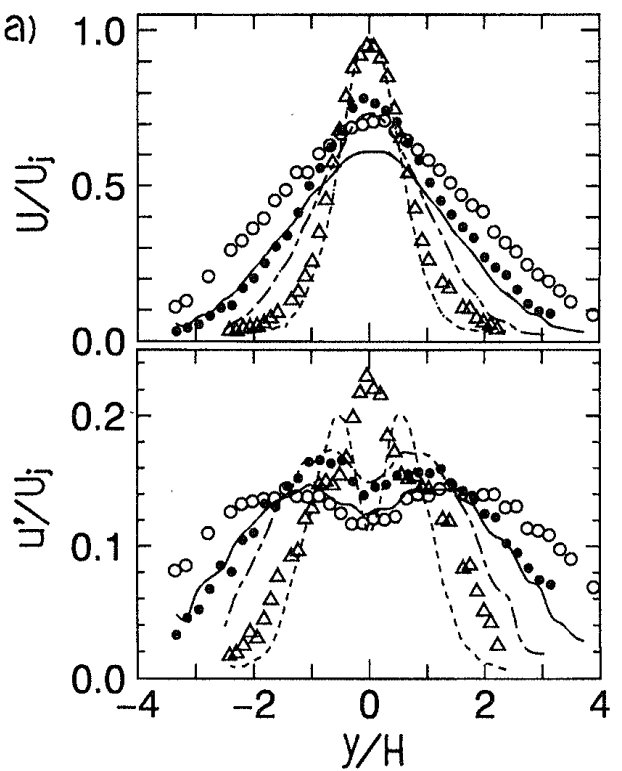

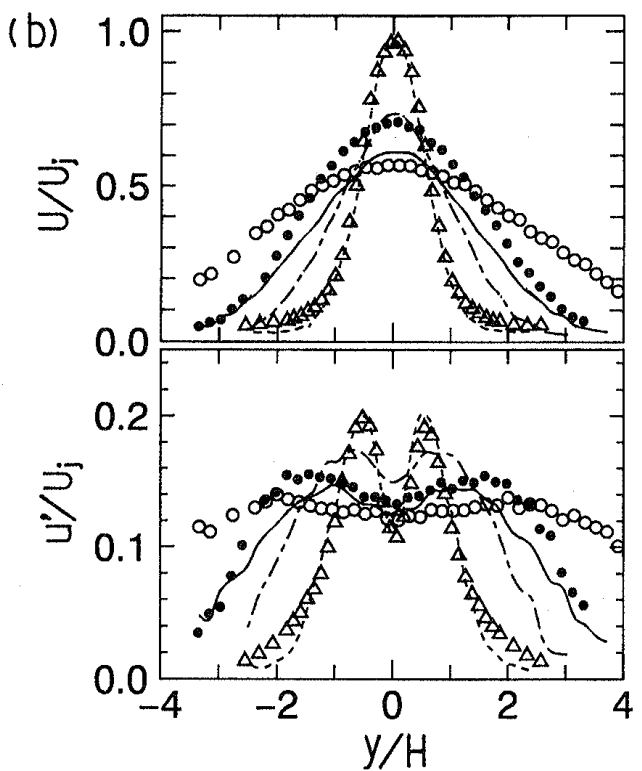

Fig. 8 Profiles of $U$ and $u$ '. (a) $S t_{e}=0.76$ (symmetric) $\bigcirc: x / H=15$. For unforced cases, $\cdots: x / H=4$,

起による $b$ の值は $x / H=4$ で非励起時よりも増すが, $x / H=15$ でも 1.3 倍程度である.また, $S t_{e} \fallingdotseq 0.4$ と 0.8 の結果はほぼ同じである。これに対し，反対称励 起による噴流幅の変化はポテンシャルくさび領域より も下流で顕著になり， $x / H=15$ で $b$ の值は非励起時 の約 1.7 倍である. 半値幅の増加に伴い連行量も増加 し, $x / H=15$ に抢ける反対称励起の值は非励起時の約 2 倍に達している。対称と反対称励起の結果の間に半 值幅のときほどの差異がないのは，中心速度の減衰の 仕方に違いがあるためである(図 8 参照)。

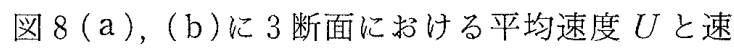
度変動強さ $u^{\prime}$ の分布を示す。図 $8(\mathrm{a})$ は対称，(b) は反対称励起の結果である。前者については $S t_{e} \fallingdotseq 0.8$ の結果のみを示した。また，比較のため，各図中に非 励起時における分布を線で記入してある。

対称励起の場合, 平均速度は非励起時よりも全体に 高くなり，噴流の広がりが増しているが, 分布形状自 体に大きな変化はない，ポテンシャルくさび終端付近 の $u^{\prime}$ 分布 $(x / H=4)$ は成長した対称かく乱による変 動の特徵を示し，中心部で最大になる， $x / H=15$ にお ける乱れ強さは非励起時に比べ中心部でやや減少し， 噴流の広がりが増したことに対応して周辺部で大きく なっている.

一方, 反対称励起においては, $x / H=4$ における $U$ とい’は非励起時とほとんど変わらない分布を示す。 励起の効果は下流に進むにつれて顕著になり， $x / H=$ 15 では $U$ とい’はいずれも非励起時に比べ中心部で

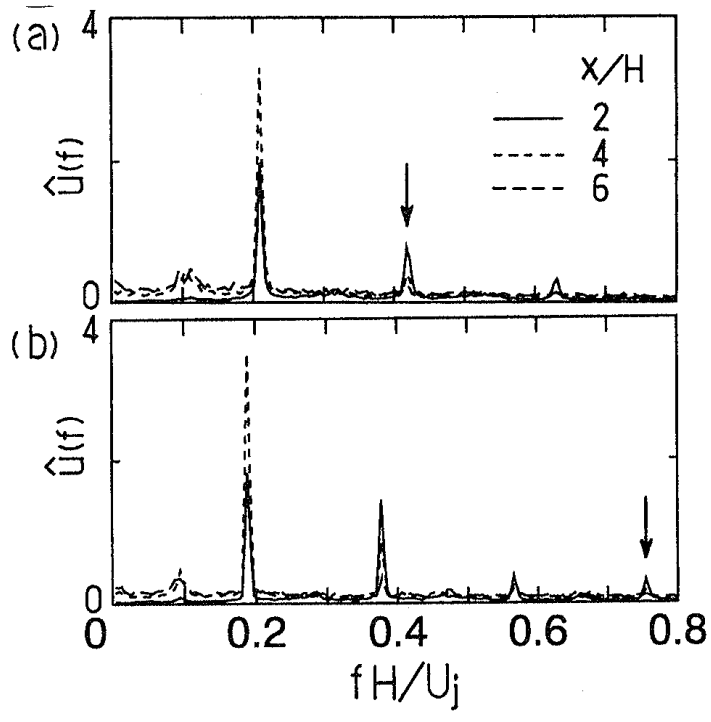

Fig. 9 Spectral evolution of symmetric disturbance. (a) $S t_{e}=0.42$, (b) $S t_{e}=0.76$. A thick arrow denotes forcing frequency. Ordinate is arbitrary in linear scale

やや減少し，周辺部で著しく大きい。

$4 \cdot 4$ 注入かく乱の挙動 図 9 (a), (b) $44 \cdot 3$ 項で調べた二つの対称励起条件に抢ける, $y=0$ 上の u変動のスベクトルである. 図 9 には $x / H=2,4,6$ の 3 断面の結果を重放て描いてある. St $t_{e} \fallingdotseq 0.4$ では $f_{e} / 2, S t_{e} \fallingdotseq 0.8$ では $f_{e} / 4$ のスペクトル成分が著しく成 長し，その結果，いずれの場合も $x / H=2$ までに卓越 周波数が $S t \simeq 0.2$ に変化している.また，この周波数 
成分は $x / H=6 に$ におても支配的であることがわか る。

この過程をさらに詳しく見るため, ポテンシャルく さび領域内の也ん断尿の縁に沿って $u$ 変動を測定し, そのスペクトルを求めた。 その結果, 注入されたかく 乱は次のようなスペクトル発展を経ることがわかっ た.

まず, St $t_{e} \fallingdotseq 0.8$ で励起したとき, 励起周波数 $f_{e}$ の成 分は $x / H \simeq 0.75\left(x / \theta_{e} \simeq 80\right)$ 加ら減衰し始め, $x / H=1.0$ 〜 1.5 で $f_{e} / 2$ 成分が局所最大振幅を示したのち, $x / H$ $=1.75$ 以降で $S t \simeq 0.2\left(=f_{e} / 4\right)$ の成分が支配的になっ た.これに対し，Ste $t_{e} 0.4$ の場合には， $x / H=1.0 \sim 1.5$ でいったん高調波の $2 f_{e}$ 成分が極大になり，その後は $S t_{e} \fallingdotseq 0.8$ のときと同様に分調波変動が成長し, $x / H \simeq$ 1.25 で $f_{e}$ 成分が, $x / H \simeq 1.75$ 以降で $S t \simeq 0.2\left(=f_{e} / 2\right)$ の成分がそれぞれ支配的になるのが観测された(図 12 参照).

これらの結果から $S t_{e} \fallingdotseq 0.4$ と0.8の対称励起によ って起こる流れ場の変化は，励起周波数成分の変動の 直接的効果によるのではなく，主として低雕波数へ変 化した変動によってもたらされることがわかる。

このような周波数の変遷を経た変動成分が初期の対 称(あるいは反対称)形の性質を維持しているか否かを 見るため，スペクトルピークを示す周波数成分の $y$ 方 向スペクトル振幅分布を求めた。 $x / H=4,10$ で得ら れた結果を図 10(a)〜 (c) に示す。

対称励起 [図 10(a), (b)] では, $x / H=4$ で $S t \simeq$ $0.2\left(f_{e} / 2\right.$, または $\left.f_{e} / 4\right)$ の成分が全域にわたって卓越し ており，他の成分も含めて対称形変動の分布を保って いる. $x / H=10$ において $S t \simeq 0.2$ の変動は反対称形 に変化しているようであるが，この位置で最も支配的 な $S t \simeq 0.1\left(f_{e} / 4\right.$, または $\left.f_{e} / 8\right)$ の変動成分は対称形の 分布形を呈している。一方，反詨称励起においては [図 $10(\mathrm{c})$ ] ，どちらの $x$ 断面に扔いても対称形をし た $2 f_{e}(S t \simeq 0.2)$ の成分が寄生しているが, $y=0$ 付近 を除き，励起周波数成分 $(S t \simeq 0.1)$ 自体が支配的で， かつ反対称形の性質を維持していることがわかる。し たがって，これらの代表的な対称，反対称励起条件下 の流れ場では，少なくとも $x / H=10$ までは，それぞれ 対称，反対称形の変動が支配的であるといえる。

これらのスペクトル発展の様子，および速度場の変 化(図 7，8)から，ポテンシャルくさびより下流の噴 流の広がりを增すには反対称励起による蛇行運動の強 化が効果的であるといえる。 (a)

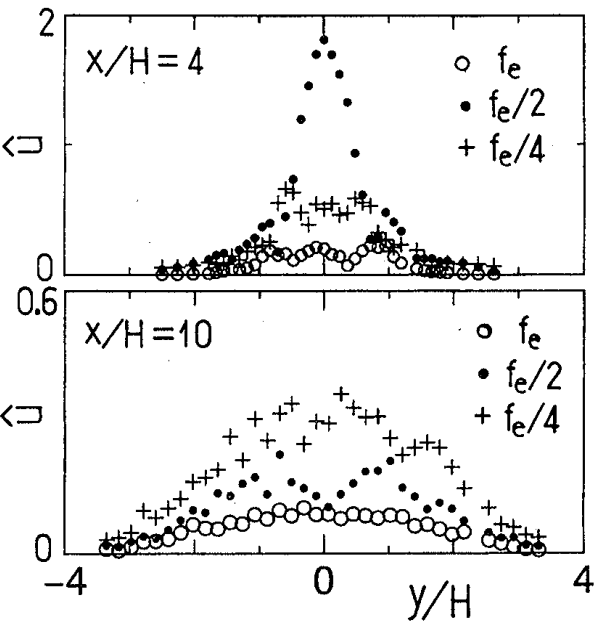

(b)

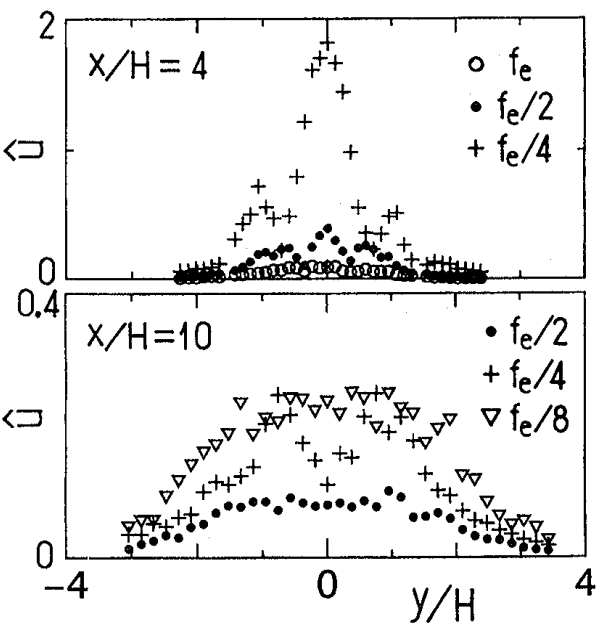

(C)

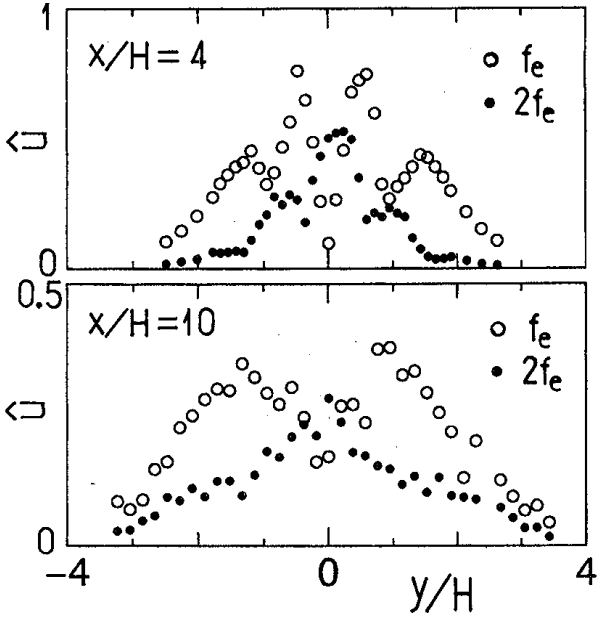

Fig. 10 Distribution of spectral magnitude. (a) $S t_{e}=$ 0.41 (symmetric), (b) $S t_{e}=0.78$ (symmetric), (c) $S t_{e}=0.11$ (antisymmetric). Ordinate is arbitrary in linear scale, but the relative magnitude between different components in each figure is correctly scaled 


\section{5. 結 果 の 検 討}

本実験の測定範囲内では, 対称励起のとき $S t_{e} \fallingdotseq 0.4$ と 0.8 , 反対称励起のとき $S t_{e} \fallingdotseq 0.1$ において速度場の 変化が大きく, その変化は反対称励起 $\left(S t_{e} \fallingdotseq 0.1\right)$ の場 合に最大になった。

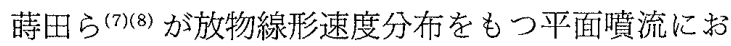
いて選定した代表周波数は対称，反効称励起に対して， それぞれ $S t_{e}=0.24$ と0.16である.ただ，これらは自 然遷移の不安定モードに基づいており，流れ場の変化 が最大になる周波数ではない可能性がある。

縮流ノズルからの平面噴流を広い励起周波数範囲 $\left(S t_{e}=0.08 \sim 1.75\right)$ で調べた Thomas-Goldschmidt ${ }^{(11)}$ の実験では噴流の広がり度が $S t_{e}=0.32$ と 0.45 付近 で極大になっており, $S t_{e}=0.1,0.8$ 付近では顕著な変 化は観測されていない。この本実験結果との間の大き な違いが何によるかは不明である。なお，彼らが与え たかく乱(ノズル出口直後で, $y$ 方向に約 $70 \mathrm{H}$ 離れた 側面からの音響かく乱) は基本的には反対称形である ように思われるが，彼らは対称かく乱であるとしてい る.また, 両実験間の励起強さの対応も不明である.

ノズル出口直後の $y=0$ 上に設置した薄板を回転振 動させて反対称かく乱を与えた Miyata ${ }^{(12)}$ の実験 では, $x / H=15$ に拉ける䠝流半值半幅と連行量が, 最 大で $2 b / H \simeq 8,\left(Q-Q_{e}\right) / Q_{e} \simeq 3$ に達している.これら は本実験で得られた值(図 7)よりもさらに大きい。た だし，彼らの実験の励起周波数は本実験のそれよりも

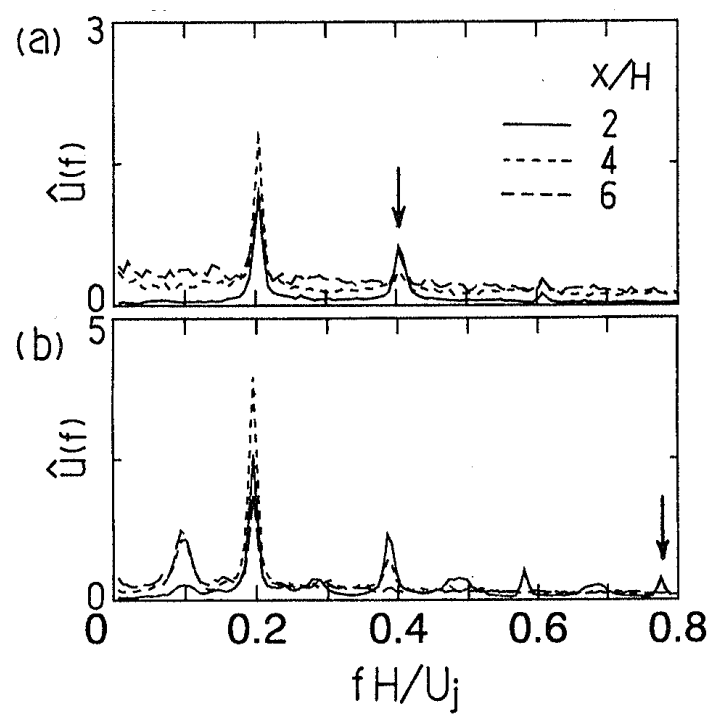

Fig. 11 Spectral evolution of symmetric disturbance at $R e=17000$. (a) $S t_{e}=0.41$, (b) $S t_{e}=0.78$. A thick arrow denotes forcing frequency. Ordinate is in linear scale
はるかに低い範囲 $\left(S t_{e}=0.006 \sim 0.02\right)$ である。

本研究で扔もに取り上げた 3 種類の励起条件では， いずれも(特に対称励起の場合) $f H / U_{j} \simeq 0.2$ の変動が 顕著に成長するのが観測された。この変動成分は風洞 気流および初期境界層中には認められなかったが(図 4)，実験結果の一般性を確かめるため, 噴流出口流速 を $U_{j}=6.3 \mathrm{~m} / \mathrm{s}\left(R e \simeq 1.7 \times 10^{4}\right)$ に変え, $S t_{e} \fallingdotseq 0.4$ と 0.8 (対称励起) に対する速度変動のスペクトル発展を 調べた。結果を図 11(a)，(b)に示す。図11より, 励起周波数 $f_{e}$ に対して速度変動の卓越周波数が $f_{e} / 2$, $f_{e} / 4$ に変化する過程は図 9 の結果とまったく同様で あることがわかる。

図は略寸が, St $t_{e} \fallingdotseq 0.2$ の対称かく乱で励起した場合 には，早朝に分調波成分が現れる現象は認められなか つた。また, St $t_{e} \fallingdotseq 0.4,0.8$ の対称励起の結果に比べ, $f H / U_{j} \simeq 0.2$ の変動の振幅が相対的に小さく, 速度場の 変化も少なかった.

\section{6.おわりに}

矩形速度分布を初期条件にもつ平面噴流に対称と反 刘称形のかく乱を与え, $x / H=15$ までの速度場の変化 を調べた．結果を非励起時と比較して要約する。

（1）対称励起では，特にSte $\fallingdotseq 0.4,0.8$ のを噴流 中心流速の減衰が遅れ，ポテンシャルくさび領域から 連行量が増大する，速度変動の卓越成分はいずれの場 合も $x / H=2$ までに $f H / U_{j} \simeq 0.2$ に変化するが，それ より下流でもその変動成分は対称形を保つ.

（2）反対称励起では， $S t_{e} \simeq 0.1$ に押いて流れ場の 変化が顕著であり, ポテンシャルくさびより下流で噴 流幅と連行量が詨称励起のときよりもさらに增大す る。乙れは平面噴流に特有の蛇行運動が反対称形かく 乱によって増長するためと考えられる。

本実験において， $a=4 \%$ 以外に励起強さを変えて 速度場を測定したのは四つの励起周波数 $\left(S t_{e} \fallingdotseq 0.1\right.$, 0.2, 0.4, 0.8)の場合だけである。また, 励起強さと流れ 場の変化の度合いとの関係は励起周波数によっても異 なる、したがって，例えば噴流幅を最大，あるいは最 小にする励起条件が本実験で設定した条件の範囲外に ある可能性もある。な抏，本測定結果は渦構造の形 成・合体などの面から見るとある程度理解しやすいよ うに思われる。しかし，本実験の測定量のみから直ち に渦構造を論ずることはできないため，これに関する 考察には触れなかった。

おわりに，実験装置の製作と改修などをしていただ いた野崎豊技官 (北海道大学)に謝意を表す。 


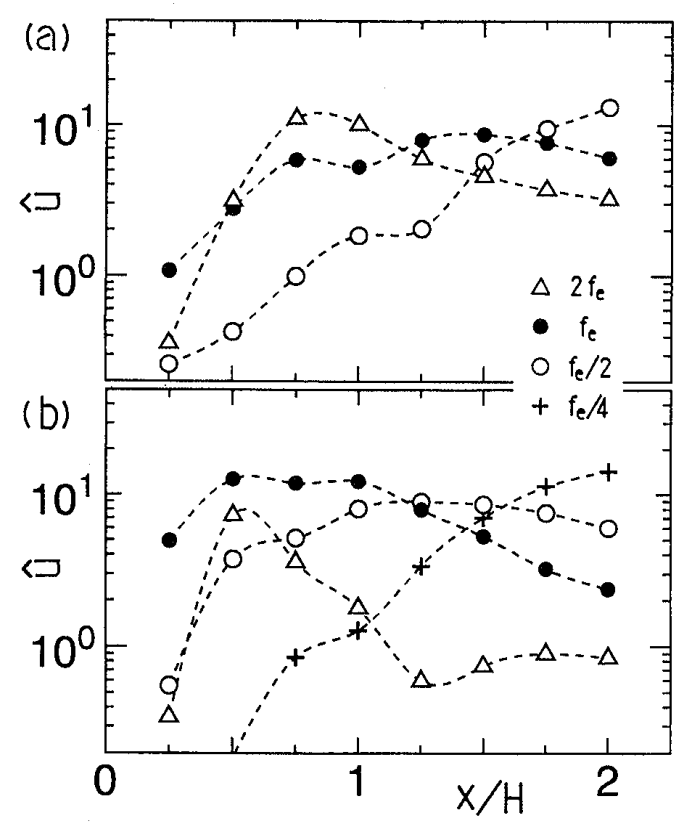

Fig. 12 Streamwise variation of the spectral magnitude of peak-frequency components, measured along a high-speed edge of the potential wedge region. (a) $S t_{e}=0.41$ (symmetric), (b) $S t_{e}=$ 0.78 (symmetric). Ordinate is arbitrary in logarithmic scale

\section{[付記]}

図 12 は, $S t_{e} \fallingdotseq 0.4,0.8$ で対称励起し，ポテンシャル くさび領域のせん断層の高速側外縁に沿って $u$ 変動 を測定したときに，スペクトルがピークを示した周波 数成分の振幅をプロットしたものである。図 12 の説 明については $4 \cdot 4$ 節を参照願いたい。なお, 図 12 は
校閲委員の指示により追加した。記して謝意を表す る。

\section{文献}

（1）佐藤 浩(谷一郎編), 流体力学の進歩「乱流」，(1980), 47-83, 丸善.

(2) Huang, J. M. and Hsiao, F. B., Phys. Fluids, 11(1999), 1847-1857.

(3) Rockwell, D. O. and Niccolls, W. O., Trans. ASME, J. Basic Eng., 94 (1972), 720-730.

(4) Browne, L. W. B., Antonia, R. A. and Chambers, A. J., J. Fluid Mech., 149(1984), 355-373.

(5) Thomas, F. O. and Goldschmidt, V. W., J. Fluid Mech., 163(1986), 227-256.

(6) Thomas, F. O. and Chu, H. C., Phys. Fluids, A1 (1989), 1566-1587.

（7）蒔田秀治・大谷秀雄 - 石角勝利, 機論, 54-504, B (1988), 1938-1945, 1946-1952.

(8) Makita, H. and Hasegawa, T., Fluid Mech. Its Appl., 21 (1993), 77-88.

(9) Rockwell, D. O., Trans. ASME, J. Appl. Mech., 94 (1972), 883-890.

(10) Hussain, A. K. M. F. and Thompson, C. A., J. Fluid Mech., 100 (1980), 397-431.

(11) Thomas, F. O. and Goldschmidt, V. W., Trans. ASME, J. Fluids Eng., 105(1986), 134-139, 108 (1986), 331-337.

(12) Miyata, M., Kurita, N. and Nakamura, I., Turbulent Shear Flows, 7(1991), 209-223.

（13）飯田誠一, 機論, 50-454, B(1984), 1500-1505

(14) Hussain, A. K. M. F. and Clark, A. R., Phys. Fluids, 20 (1977), 1416-1426.

(15) Chambers, A. J., Antonia, R. A. and Browne, L. W. B., Exp. Fluids, 3(1985), 343-348.

(16) Ross, J. A., Barnes, F. H., Burns. J. G. and Ross, M. A. S., J. Fluid Mech., 43(1970), 819-832.

(17) Hussain, A. K. M. F., Phys. Fluids, 26 (1983), 2816-2850.

(18) Ho. C. M. and Huerre, P., Ann. Rev. Fluid Mech., 16 (1984), 363-424. 